\title{
Beyond property: Rural politics and land-use change in the Colombian sugarcane landscape
}

\author{
Irene Vélez-Torres ${ }^{1}$ (1) | Daniel Varela ${ }^{2,3,4}$ | Víctor Cobo-Medina ${ }^{1,5}$ | \\ Diana Hurtado ${ }^{1}$
}

${ }^{1}$ School of Natural Resources and Environmental Engineering, Universidad del Valle, Cali, Colombia

${ }^{2}$ Anthropology and History, University of Michigan, Ann Arbor, Michigan

${ }^{3}$ CES, Universidad Nacional de Colombia, Bogotá, Colombia

${ }^{4}$ Group of Social Anthropology, ICANH, Bogotá, Colombia

${ }^{5}$ Research on Sociology, Facultad Latinoamericana de Ciencias SocialesFLACSO, Quito, Ecuador

\section{Correspondence}

Irene Vélez-Torres, School of Natural Resources and Environmental Engineering, Universidad del Valle, Calle 13 \#100-00, Cali 439, Colombia.

Email: irene.velez@correounivalle.edu.co

Funding information

Universidad del Valle \& Universidad Nacional de Colombia; ICANH

\begin{abstract}
Analysing the sugarcane landscape in the flat valley of the Cauca River (Colombia) reveals that agricultural industrialization in the region required the concentration of land use by regional industrialists and the corresponding exclusion of landowners and poor peasants from territorial decisionmaking processes. The analytical lens used in this article, based on the use and control over land and land-based natural commons, allows for the characterization of three periods in a non-linear process of articulation and dispute between poor peasant and capitalist agents in the expansion of the sugarcane monoculture during the 20th century. The different constellations of social agents, governmental nexus, and capital enclosures have enacted through mechanisms that, beyond concentrating land property, have managed to deprive rural ethnic communities from their cultural and environmental heritage, traditional economies, and possible futures.

\section{KEYWORDS}

agrarian change, agrarian modernization, commons, land property, land use, monoculture
\end{abstract}

\section{1 | INTRODUCTION}

In April 2018, in the run-up to the presidential elections, leftist candidate Gustavo Petro visited the predominantly black town of Puerto Tejada, which is located at the heart of the sugarcane growing region in south-west Colombia, one of the most technological and productive agro-industrial landscapes in the world. After his visit, he proposed 
that Carlos Ardila-Lülle, one of the country's wealthiest men, sell his Incauca sugarcane mill to the Colombian state. Petro argued that "30,000 hectares of land must be set aside for the communities to produce a variety of products and industrialize the region." In response, the president of Asocaña, the national association of sugarcane growers and mills, appeared before the media and stated that "of the 243,232 hectares planted with sugarcane in the Cauca River Valley, $75 \%$ belongs to 2,750 producers different from those of the sugarcane mills; [independent producers that] provide raw material to the sugarcane processing companies." ${ }^{1}$ With this response, the Colombian sugarcane industry countered the criticism that they had engaged in land grabbing in the Cauca Valley and controverted the widespread idea that the 13 sugar refining companies in the Cauca Valley are the owners of the land.

This electoral debate touching upon the issue of land grabbing and distribution in Colombia reveals three things: (a) There is a lack of knowledge about the complexity of interests and socio-economic agents that constitute the sugarcane landscape of the Cauca River Valley; (b) this diffuse vision of rural politics in the sugarcane landscape limits criticism, because it directs criticism to the problem of land grabbing without addressing the problem of land-use grabbing; and (c) the perpetual confusion over the dynamics of land ownership and land use risks the creation of misguided public policy, while separating the sugarcane industry from its responsibilities for the social, cultural, and ecological impacts of land and land-use grabbing.

With this article, we seek to help close this research gap and reflect upon the history of relations between the four different agents that have coexisted and shaped the current sugarcane landscape in Colombia: the sugarcane industrialists, the landowners' sugarcane suppliers, the leasing sugarcane suppliers, and the peasant communities in the region. We investigate the differentiated role that the central Colombian state has played in configuring the landscape of the valley and contribute to the conceptual differentiation between land grabbing and land-use grabbing in the context of an agro-industrial economy.

The history of the sugarcane landscape in the Cauca River Valley during the second half of the 20th century demonstrates that agricultural industrialization does not need a high concentration of land ownership. It does need, however, the concentration of land use by regional industrialists and the corresponding exclusion of landowners and poor peasants from territorial decision-making processes. Land-use grabbing has, consequently, deepened the inequality among local actors in terms of their ability to access natural resources and participate in the micropolitics of territorial management. However, the fact that the land-tenure structure has not evolved into a high concentration of land property has been used by industrialists as a pretext to ignore their responsibility in constraining poor rural inhabitants currently confined to urban centres such as Puerto Tejada.

To investigate the historical politics of the sugarcane agroindustry in Colombia, this article is structured as follows. First, we propose a conceptual dialogue between the debate on land use and ownership and debates on the privatization of common goods. Second, we introduce the methodology and the case study. In the third section, we lay out the article's central corpus, which consists of a detailed description of three historical periods, categorized according to the different constellations of agents and interests. This description guides our analysis towards a non-linear understanding of the formation of the sugarcane landscape in the Cauca River Valley. The concluding remarks address the different ways in which the industrialization of sugarcane cultivation has been the result of differentiated interests and alliances among agents that have resulted in damages (in the case of the rural poor) and accumulated wealth and privileges (in the case of the capitalist elites). The importance of land use in understanding the Colombian sugarcane landscape, rather than solely relying on the examination of land property, calls for a renewed analysis of the defining features in the exercise of territorial control and agrarian change.

\footnotetext{
${ }^{1}$ See the letter sent by the Asocaña president Juan Carlos Mira in http://juanpaz.net/wp-content/uploads/2018/04/asoca\%C3\%B1a.pdf.
} 


\section{2 | CONCEPTUALIZING AGRARIAN POLITICS AND THE SUGARCANE LANDSCAPE}

The concept of landscape has been adopted from geography and ecology. Its use is associated with the joint analysis of the morphological and functional characteristics of a territory (Vila Subirós, Varga Linde, Llausas Pascual, \& Ribbas Palom, 2006) over a surface whose scale is delimited due to eco-geographical homogeneity (Muñoz Guerrero \& Gómez-Zotano, 2016). Although in many cases, the landscape is analysed based on its natural features, the dynamic nature of morphological and functional characteristics raises concerns about the social processes that influence their changes and transformations. In this regard, the understanding of landscape as a social term avoids naturalistic determination in landscape formation, placing the locus of change on socioecological interactions (Bürgi, Hersperger, \& Schneeberger, 2005; Gosden \& Head, 1994; Hersperger \& Bürgi, 2009).

Considering landscape as a socioecological system has resulted in the integrated analysis of time-space structures (a) formed by ecosystem processes and anthropogenic transformations and (b) expressed in specific landtenure patterns (Marull, Pino, Tello, \& Cordobilla, 2010). This approach invites us to understand social relations as determinants of the historical configuration of geo-ecological surfaces while incorporating the constellation of social agents, economic interests, and political relations in such landscape crafting. From this perspective, the Colombian sugarcane landscape can be analysed as an interactive process that, over the last six decades, has merged the homogenization of nature in the Cauca River Valley with social, political, and economic drivers of agrarian industrialization.

Although various studies have referred to the relationship between landscape and property in the context of England (Sullivan \& Osborne, 1998; Williamson \& Bellamy, 1987), the landscape approach has extended the application of socioecological systems to other land-tenure regimes (Brunckhorst, 2010). As argued by Borras and Franco (2012), the politics of land use and property relations have been poorly explored in the literature, leading to a gap in the understanding of how those two dimensions interact and why their differences matter in the agrarian debate. In this context, a better understanding of land tenure and its relationships with landscape formation represents an important contribution to critical agrarian researchers and the challenge of understanding land deals in the current convergence of global food, energy, and environmental crises (Borras, Hall, Scoones, White, \& Wolford, 2011).

Land property has been understood as a particular form of ownership that differs from and interacts with other land-tenure patterns and processes of appropriation, such as the right of possession, the right of use, the right of access, the right of disposal, the right of operation, the right of demand, and the right of inheritance (Yifeng, 2008). The concept of property refers to the ways in which wealth is formally acquired, used, and transferred in society; its multifunctional nature relates property to the political order and to different forms of territorial power (Von BendaBeckmann, von Benda-Beckmann, \& Wiber, 2006). This is why property has been conceptualized based on the social relations that underlie and emerge from the formal title of possession. As such, different social interactions with nature could lead to enduring legacies of privilege and power (Tello, Jover, Murray, Fullana, \& Soto, 2018).

Hence, a broad analysis of land property involves analysing ownership as much as the multiple determinants in the actual exercise of control over land, such as the direction, pace, and scope of changes in land use (Hall, 2011). In particular, it seems relevant to understand the difference between land use and property to establish its impact on "the direction of the transfer of the effective control over land-based wealth and power" (Borras \& Franco, 2012, p. 50). By effective control, we refer to the individual and collective capacity and freedom to decide why and how to (a) access nature, (b) organize unpaid work and waged labour, (c) distribute surplus production, and (d) dispose waste, damage, and other negative externalities.

In the configuration of the Colombian sugarcane landscape and its land-tenure regimes, four types of social agents stand out. To characterize them, we are guided by four key questions about agrarian political economy outlined by Bernstein (2010): who owns what, who does what, who gets what, and what is done with the surplus. The 
current agrarian agents are identified according to the relationships between ownership and production and include the following:

- The industrialists own the sugar mills and ethanol factories and a quarter of the land cultivated with sugarcane. They transform sugarcane and accumulate wealth through the commercialization of its derivatives. As the required raw material for this industry, $25 \%$ of the sugarcane is obtained from their land, whereas the remaining $75 \%$ comes from third-party suppliers or rented land. They invest part of the surplus in technology development.

- The landowners hold three quarters of the land cultivated with sugarcane in the Cauca Valley. They accumulate wealth (a) through sugarcane production sold to the refining companies and (b) by renting land where the sugarcane is cultivated by the mills or third parties. This is a highly heterogeneous sector in terms of the extensions of land accumulated by its members; however, the members share the same interests in terms of renting their land or selling their production to the mills. They invest part of the surplus in technification provided by the sugar mill industry.

- The leasing suppliers do not own any portion of the Cauca Valley's land, but they rent land from landowners. They accumulate wealth through sugarcane production sold to the mills in different stages of production and modalities of trade. They invest part of the surplus in technification provided by the sugar mill industry and land rented from traditional landowners.

- The peasants or poor rural inhabitants are composed of Afro-descendant, indigenous, and mestizo groups that were previously organized in subsistence agricultural communities that reproduced their economy, culture, and ecology in confined and marginal spaces. Losing most of their access to land and land-based resources, they suffered the damages of agro-industrial accumulation. A small fraction of these inhabitants are associated with manual labour in sugarcane cultivation, whereas few others, who may still own some land, struggle to maintain their traditional farms. Due to the challenges of holding onto traditional land use, some peasants also grow sugarcane and sell it to the mills. However, the large portion have lost their agricultural land and live unemployed and confined in regional urban centres.

During the first half of the 20th century, pioneering businessmen purchased old haciendas to establish sugar mills. In 1952, 25.225 ha of sugarcane were cultivated on these haciendas to supply the industrialists' mills, whereas they also diversified their production by raising cattle (Dávila \& de Guevara, 2013, pp. 209-248; Rojas, 1983, p. 118). It was only in the 1950s that the industrialists and the landowners became differentiated, as landowners were largely reluctant to shift from livestock to an industrial crop grown for export.

However, sugarcane industrialists were not as interested in land ownership as they were in cultivating sugarcane on landowners' property. As a result, the industrialists paid high prices to landowners to cultivate cane on their land, and the landowners agreed to change the use of their land to receive this payment. This agreement allowed the group of regional industrialists to encourage the planting of 135,000 new hectares between 1960 and 1998 in the upper Cauca River basin. Half of a century after reaching such agreement and facilitating the massive increase in the sugarcane crop, the agro-industrial sector produced 243,232 metric tons raw value of sugar per year (Asocaña, 2018).

Initially, their alliance with the industrialists strengthened the landowners' opposition to the agrarian reform policies promoted by the central government in the early 1960s; joint action against the government's measures of purchase and land expropriation allowed landowners to maintain land ownership. The alliance also led to the breakdown of previous social contracts, such as the interdependence between landowners and the hacienda labourers who inhabited the wetlands and forests around the Cauca River Valley. Sugarcane suppliers gradually formed a social sector that included landowners and the sugarcane growers who rented the land; they could guarantee the provision of sugarcane to the mills that were strictly produced under technical conditions that they established.

The distinction between land property and land use allows for an understanding of how the change in land use significantly affected the lives of the rural poor even though the structure of land ownership was not greatly altered. 
Raising cattle was the predominant productive model in the Cauca Valley during the 19th and first half of the 20th century. Although landowners owned most of the land, they only exploited the nonflooded areas of these plains (Perafán, 2014; Valencia-Llano, 2015, pp. 19-36); by contrast, the flooded forests and the wetlands were living spaces used by black and indigenous day labourers from the haciendas (Taussig \& Rubbo, 2011; Vélez-Torres \& Varela, 2014; Vélez-Torres, Varela, Rátiva, \& Salcedo, 2013). In this model, land ownership was private, whereas the use of land was communal: The commons in the Cauca River Valley, locally named "montes oscuros" [dark forests], were cocreated, protected, and used by the local rural communities.

During the 20th century, when the hacienda model was transformed and the agro-industrial sugarcane landscape consolidated, losses of up to $72 \%$ of wetland ecosystems and $66 \%$ of flooded tropical dry forest were reported (Perafán, 2014). These changes reflect the ways in which appropriation transformed the natural environment, in particular, the processes of deforestation and drying of wetlands for sugarcane monoculture.

To the extent that the landscape changed, the spaces of interest for the landowners were expanded, and the communities that inhabited these regions and used the land in these territories-without necessarily owning that land-were gradually displaced and relocated to the confined spaces of nearby cities and mountain ranges adjacent to the fertile valley of the Cauca River.

To analyse these drastic socioecological transformations, the categories provided by McCay and Acheson (1990) and Ostrom et al. (2002) of access and real governing of the commons are useful. The authors' argument begins by explaining that there is differentiated access to the commons and, consequently, a different reception to the outcomes of its transformation and privatization processes: loss and damage for some (drama) and accumulation and privilege for others (comedy). The differentiated access to the common pool of resources allows us to question power relations and the direction in which they drive the distribution of labour, capital, and nature (Raworth, 2017). In what follows, we uphold this discussion as a conceptual key to analysing the sugarcane landscape in Colombia in relation to the distribution of privilege and damage associated with the change in land use.

\section{3 | CASE STUDY AND METHODOLOGY}

The sugarcane cluster in the Cauca River Valley in Colombia has frequently been studied as a successful case of agro-industrial development focused on sector integration and technological innovation. Today, it produces sugar, ethanol, sugarcane-based liquor, and other derivatives and represents $0.7 \%$ of the national GDP, 3.7\% of the agricultural GDP, and $5 \%$ of the national agricultural exports (Asocaña, 2018). Such economic development is based on the more than 243,000 ha planted in the flat valley of the Cauca River (see Figure 1), which is equivalent to $4 \%$ of the cultivated agricultural area of the country.

Through the development of crop varieties based on microclimate and the innovation of maturation techniques through the application of glyphosate (Hurtado, 2017), the sugarcane productivity per hectare increased from 88 tons in 1960 to 118 tons in 2017. In this same period, sucrose concentration also increased from 5.3 to 14.2 tons/ha harvested. Additionally, the average harvesting age for sugarcane was reduced from 18.8 to 11 months (Asocaña, 2018; National Productivity Centre Colombia, 2002).

Our methodology seeks to reconstruct this historical case, contrasting the views of different social agents, mainly those who have been marginalized from control over the land: poor peasants and, paradoxically, landowners. We obtained the voices of the peasants from memory reconstruction in two focal communities located in former hacienda areas of El Tiple and El Hormiguero. Both populations are known for taking action to denounce the effects generated by sugarcane monoculture. To collect landowner voices, we relied on an exhaustive review of the correspondence maintained between them, the central government and the industrialists (1963-1971), as well as on their internal dissemination body, the Agricultural and Livestock Magazine (1951-1964), and documents currently housed in the historical archive of the Society of Farmers and Cattle Ranchers of Cauca Valley (Sociedad de Agricultores y Ganaderos del Valle del Cauca [SAG]). 


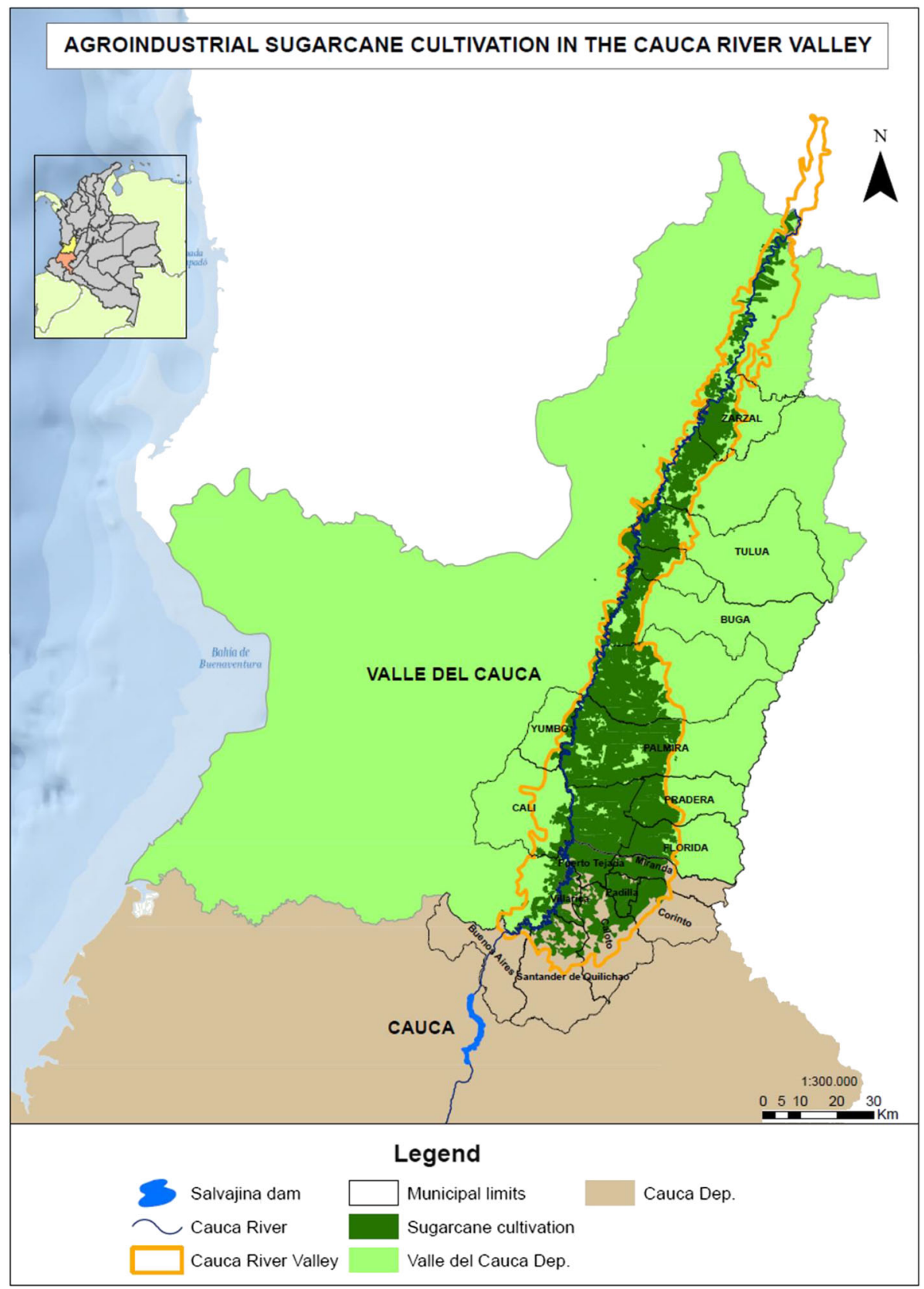

FIGURE 1 Location map of sugarcane cultivation in the Cauca River Valley.

Source: Own design

The following sections of this article address the historical configurations of the sugarcane landscape in chronological order. The first section defines the antecedents prior to 1954, characterizing the economic model of the hacienda in which landowners established a paternalistic cooperation with poor rural inhabitants. The second section characterizes the period from 1954 to 1963 and analyses the alliance between the sugarcane industry and the central government. The third section analyses the period from 1964 to 1974, in which an alliance between landowners and industrialists consolidated, giving rise to the new sugarcane guild. The fourth section describes the period from 
1975 to 1998 and the hegemonic position of the industrialists, who control the technology involved in sugarcane production and land use in general.

\section{4 | PERIODIZATION OF THE SUGARCANE AGRARIAN FORMATION}

\section{1 | Background-The hacienda model in the Cauca River Valley and the origins of the sugarcane industry through the $1950 \mathrm{~s}$}

The Cauca Valley haciendas originated in the Spanish Colonial period during the 18th century. Haciendas were established by Spaniards or their descendants, and labour was provided by African slaves who worked raising cattle and producing sugarcane. The haciendas flourished thanks to their commercial links with the colonial gold mining sector, providing the mining regions with meat, sugarcane-based liquor, and slave labour (Colmenares, 1976). Even though the haciendas' production decayed during the 19th century due to both the crisis of the mining sector and the cost of the wars for national independence, most of the owners kept the landholding and the cattle haciendas in the family until the first half of 20th century (Almario, 1994; Díaz, 1983, p. 94).

The hacienda model involved rotating livestock between the stagnant flooded areas of the Cauca River (40\% of the flat areas for 6 months every year) and the areas that remained dry. After slavery was abolished in 1951, the haciendas paid low wages but retained their labour by incentivizing the peasant economies: In the lagoons and flooded forests of their property, Afro-descendant communities subsisted on fishing, basic food crop agriculture, and sales of coffee, cocoa, and banana while they also worked at the hacienda (Valencia-Llano, 2015, pp. 21-36; Vélez-Torres \& Varela, 2014; Vélez-Torres et al., 2013). This economic arrangement established a framework of paternalistic relations that sustained the regional political power of the landowners during the 19th and first half of the 20th century.

During the initial decades of the 20th century, the first sugarcane mills were founded in the Cauca Valley: Manuelita in 1901, and Riopaila and Providencia in 1928. Before these three pioneering sugarcane mills were established, their owners became landowners: They bought some of the most prominent haciendas to produce sugarcane and to supply their mills. At the same time, they diversified their investments in other local industries, financial corporations and, mainly, in raising cattle on the same haciendas (Dávila \& de Guevara, 2013; Rojas, 1983). With the entry of another 13 mills in the period from 1930 to 1950 (Fedesarrollo, 1976), the first industrial sugarcane guild consolidated and differentiated from the landowners' sector. The new industrialists were landowners who followed the entrepreneurial example and decided to formally become industrialists.

Consolidating the industrial unification allowed for the collaboration and arrangement of interests with the national government. This process was expressed in the creation and promotion of the Lending Society of the Sugarcane Sector (Seccional de Crédito Azucarero) in 1933, the formation of the Sugar Distribution Company (Compañía Distribuidora de Azúcar) in 1937, and the foundation of the Cauca Valley Chapter of the National Association of Colombian Industrialists (Asociación Nacional de Industriales de Colombia-ANDI Seccional Valle del Cauca) in 1944 (Collins, 1983). Prior to this time, each mill was responsible for providing its own raw material through the cultivation of sugarcane on its own properties. To grow, this industry needed more land, but land in the Cauca Valley was a limited resource due to the control exercised by the haciendas. The industrialists aimed to solve their limited access to land by creating an alliance with the national government to pressure landowners to grow sugarcane.

\section{2 | Period I-Landowners oppose the agro-industrial model and poor rural inhabitants coinhabit "useless" ecosystems (1954-1963)}

To avoid communist uprisings, in the early 20th century, the United States promoted liberal policies in Latin America towards the redistribution of land ownership as a basis for agricultural productivity. In Colombia, two international missions defined precise pathways for designing development policies: the Currie plan and the Lilienthal plan (Presidencia de la República, Dirección Nacional de Planeación Económica y Fiscal, 1954). 
The Currie plan proposed an investment and tax programme that was partially implemented by the central government between 1950 and 1953; this policy proposed a progressive increase in the property tax on rural property if its exploitation did not reach a minimum productivity level in relation to its commercial valuation. The soils of the Cauca Valley were classified as the most fertile in the country and, therefore, were subjected to a high tax to discourage the unproductive extensive livestock model.

As the discussion and approval of this measure progressed, the Cauca Valley landowners reacted through their main dissemination body, the Agricultural and Livestock Magazine, in which they stated:

To lead the Cauca Valley landowners to abandon grazing by coercive means such as fines, confiscations or excessive taxes, it is necessary that the state offer them an (...) efficient irrigation plan for their farmland. ${ }^{2}$

In the same text, the landowners complained that:

The floodplains of the valley would suffer from the alleged lien (...), which would create a situation of aberrant injustice for the owners of these lands, trying to convert them by compulsory means, from shepherds, as is their nature, to farmers, as the Currie plan wants. (...) In these conditions, agriculture on a large scale is not an economic exploitation, but an adventure. ${ }^{3}$

Almost in response to this request from the landowners, in 1954, the Lilienthal plan-entrusted to the Director of the Tennessee Valley Authority-proposed converting the Cauca River Valley "[...] into a perfectly irrigated, dried land dedicated to intensive crop production of high performance and high price in the [international] market" (Lilienthal plan: 4). This plan recommended moving ranching to the mountains and devoting the flat areas to intensive cultivation of products for industrial use (Lilienthal plan: 34). In addition, the director presented an ambitious agenda for energy development, road infrastructure, and improvement of the Buenaventura Port on the Pacific Ocean. The Cauca Valley Corporation (CVC) was proposed as the executive body, and it urged financing through an additional tax on the already increased land cadastre.

In the words of the landowners, the Lilienthal plan increased the "unbearable" tax burden on their properties by $100 \% .{ }^{4}$ Once again, the landowners used their magazine to lash out against this plan and against the CVC, arguing that they were nothing more than "beasts of Peronist intonation," ${ }^{5}$ referencing the military dictatorship of Rojas Pinilla, who was unfamiliar with regional particularities and interests:

As stated in numerous timely advertising documents, farmers and ranchers in the Cauca Valley have made substantial fixes to the so-called Lilienthal plan or CVC, both for its origin of totalitarian accent and for its organization. [The plan is] turning its back on our economic possibilities and objectivesthat imply the manifest pretension of our immediate and urgent needs, such as irrigation, drainage and roads. [And is doing so] to welcome fabulous and chimerical electrical prospects, which have the clear sense of a criollo plagiarism of foreign prospects of peoples whose economy does not maintain parity with the modest Colombian realities. ${ }^{6}$

\footnotetext{
${ }^{2}$ Revista Agrícola y Ganadera [Agricultural and Livestock Magazine] No. 133, Feb. 1951: 3. "The SAG's concept of the Currie Plan and farmers," written by Ernesto González Piedrahita, president of the Valley Farmer's Society.

${ }^{3}$ Revista Agrícola y Ganadera [Agricultural and Livestock Magazine] No. 133, Feb. 1951: 3. "The SAG's concept of the Currie Plan and farmers," written by Ernesto González Piedrahita, president of the Valley Farmer's Society.

${ }^{4}$ Revista Agrícola y Ganadera [Agricultural and Livestock Magazine] No. 199, Dec. 1956: 9. "Report by the SAG's President, period January to December 1956," written by Ernesto González Piedrahita, president of the Valley Farmer's Society.

${ }^{5}$ Revista Agrícola y Ganadera [Agricultural and Livestock Magazine] No. 206, Jul. 1957: 17. "Memorial of the Farmers and Cattle Ranchers to the military executive board of the government about the Lilienthal Plan-CVC," presented by SAG and the Ranchers Committee of the Valle.

${ }^{6}$ Revista Agrícola y Ganadera [Agricultural and Livestock Magazine] No. 206, Jul. 1957: 17. "Memorial of the Farmers and Cattle Ranchers to the military executive board of the government about the Lilienthal Plan-CVC," presented by SAG and the Ranchers Committee of the Valle.
} 
Through agricultural industrialization and agricultural product exports, the Currie and Lilienthal plans adopted by the central government proposed capital accumulation for reinvestment, employment generation, and economic development of the country. In this vision, the nascent agro-industrial sugarcane sector was a strategic ally. As long as landowners maintained their strong opposition to changing their livestock model and to risking investment in agribusiness, they were a spoke in the wheel. How then was the Cauca Valley productive landscape to be changed?

Sanctioned in 1961, Agrarian Land Reform Law 135 deepened the alliance between the sugarcane industry and the central government to the detriment of the landowners. This alliance is more than evident when we consider that the first director of the Colombian Institute for Agrarian Reform (INCORA) was the economist Enrique Peñalosa Camargo, who had worked as a consultant hired by the sugarcane industry guild in that same year. In his report for the mills on the prospects of the sector, Peñalosa highlighted the potential for growth if, among other factors, a conversion from cattle pasture to sugarcane plantation in the valley could be realized (Fadul \& Peñalosa, 1961). From this perspective, the Agrarian Land Reform Law seemed to provide an excellent strategy to force this transition.

The landowners reacted again, and this time, they protested against sugarcane industrialists and owners of sugarcane mills, whom they accused of being the true owners of the large estates in Cauca Valley. In 1958, the year in which the Agrarian Land Reform Law was discussed in Congress, the annual report to the General Assembly of Livestock Breeders, presented by its president Camilo Molina Ossa, stated that:

The giant extension covered with sugarcane that service the sugarcane mills, some of them family enterprises with more than 20,000 positions, are dilated beyond any calculation. (...) The large expanses are not in the hands of the haciendas, as the CVC and its unofficial defenders have been defending. (...) The state is complacent with the large companies dedicated to sugarcane monoculture because it estimates that they require numerous hands. (...)

This is how the Cauca Valley people of the countryside have been evicted. The families of owners, stewards, aggregates and small landholders, the majority of whom are dispersed and impoverished, lament the economic wreck in the cities; various crops disappeared and the fruit trees of the family gardens that were destroyed along with the wooden hedges before the avid electrical demands of sugarcane; the cows disappeared, the imbalance has reached such a point that even the birds do not have a place to nest. The family has been replaced by the wage-earner, a moving mass that passes from one mill to another (...). With the dispersion of the family and the destruction of the flora and fauna, monoculture triumphs, food sources have been scarce and have partially disappeared. (...) Everything has been destroyed from the invasion of the sugarcane crop. ${ }^{7}$

When referring to a hacienda as an area where "owners, stewards, aggregates, and small landholders" lived idyllically and where the Cauca Valley family was possible, Molina Ossa was defending not only land ownership and the livestock economy but also the model of paternalistic hegemony, which worked through a tacit alliance between the landowners and the peasant day labourers. In this alliance, the peasants were allowed to live on the flooded lands considered unproductive while organizing their workforce for the ranching or agricultural work of the haciendas. An indigenous person of the region describes this system as follows:

[This hacienda] had a lot of livestock and at its lower end had a very nice guava orchard. But because they said it was wet, they said no, that this land was not useful (...). Some said that this land only

${ }^{7}$ Revista Agrícola y Ganadera [Agricultural and Livestock Magazine] No. 216, Oct-Nov. 1958: 15-17. "Report by Dr. Camilo Molina Ossa in the general Assembly of Cattle Ranchers on the 27th of October 1958." 
served to grow toads. But we live there, and (...) that [land] has given us food that we did not have before, it has provided us everything. ${ }^{8}$

The flooded zones, despised by both landowners and sugarcane industrialists and by the development model of the period, provided living space for poor rural inhabitants. Where the landowners saw useless marshes, the ethnic communities found a place where they could reproduce their environment, culture, and subsistence economy. Today, 70 years later, nostalgia for this old model is expressed in the memories of an elderly man who lived and worked on a cattle ranch. His story seems to mirror the words of Molina Ossa.

Before, there were farms that fed the birds, there were all types of fruits: there were plantain, guineo, banana, good fruits and everything, and they were tasty, they had good food. Then, when the farms started running out, the rich man got hold of them [to plant sugarcane], and then there was more crisis, and there was no such variety [of food] as there was before. Not for the birds or for anyone. All that was good is no longer seen. ${ }^{?}$

This perspective allows us to see the intimate arrangement between the black peasant population and landowners in the old paternalistic regime. Although the hacienda model implied certain labour dependency, it also offered Afro-descendants an opportunity for autonomy that was particularly associated with access to an ecologically rich environment. Thus, nostalgia for the hacienda is configured from these rural poor being deprived of that access to environmental goods and of relative inclusion in the socio-economic relationships implied in the hacienda model. Currently, both autonomy and relative inclusion are lost to poor inhabitants of the Cauca River Valley, illustrating the dramatic loss of land-use and sociocultural relationships within the territory generated by agro-industrialization.

\section{3 | Period II-The alliance between landowners and industrialists and the exclusion of poor rural inhabitants (1964-1974)}

Between 1962 and 1974, the sugarcane industry experienced unusual growth. The area planted with sugarcane in the Cauca River Valley increased from 32,211 to 96,939 ha. Most of the newly cultivated hectares were not owned by sugarcane entrepreneurs but by those who rented their land to the mills or who started to grow sugarcane independently, mostly on rented land; the latest were called "suppliers." During these years, the participation of independent suppliers increased the area planted with sugarcane from 5,411 to 41,727 ha, which demonstrates the sugarcane industry's success in co-opting land used. Meanwhile, the amount of land leased to the mills by these long-time landowners increased from 3,521 to 16,815 ha (Rojas, 1983, pp. 142-149). The above data reveal a new period in the relationship between landowners and industrialists.

The creation of Asocaña in 1959, the most important industrial sugarcane guild to date, contributed to surmounting the age-old quarrels between landowners and industrialists. To provide context, the central state formulated the so-called National Sugarcane plan, which was budgeted to incorporate 300,000 ha of land in the flat areas for sugarcane production and to establish four new sugarcane mills to obtain 60 million bags of raw sugar; these plans occurred in the historical context of the Cuba crisis and a decreasing supply in the North American market. ${ }^{10}$ Although the United States' supply of sugar was increasingly dependent on Cuba's expansion of sugarcane plantations under foreign control (Dye \& Sicotte, 2004; Higman, 2000), the Cuban revolution in 1959 generated a

\footnotetext{
${ }^{8}$ Interview with a 60-year-old indigenous woman from Caloto, Cauca. November 2016.

${ }^{9}$ Interview with an 80-year-old Afro-descendant man from El Hormiguero, Valle del Cauca. March 2016.

${ }^{10}$ Revista Agrícola y Ganadera [Agricultural and Livestock Magazine] No. 251, Jun. 1963: 23. "Farmers' and ranchers' comments"; No. 252, Oct-Nov 1963: 12-19. "What is the national sugarcane plan - a proposal to the Colombians" \& " 40.000 hectares of sugarcane will be cultivated in the Valle in 1965 " by Jaime Lozano Henao, Asocaña President. See other references to the Plan Nacional Azucarero [National Sugarcane Plan] in further editions of the magazine in 1964, 1965, and 1966.
} 
breakdown of existing business relationships that created new expectations for commerce on the part of other sugarcane-producing regions such as Colombia.

The pressure exerted by the Sugarcane plan for accessing the land of the landowners is expressed in two cases of land expropriation attempts: the first relates to Hacienda Castilla in the municipality of Cartago, owned by Abraham Mesa Pajón (1963), and the second to land consolidation in the municipality of Jamundí, at Hacienda La Berta, owned by Carlos Blum Caicedo and Rodolfo Tobón ${ }^{11}$ (1970; Villamil Chaux, 2011). In both cases, the Colombian Institute for Agrarian Reform was the most important governmental actor pressuring those landowners who remained reluctant to grow sugarcane. Although the landowners eventually yielded and grew sugarcane, we will show that they did not accept the conditions of the central state but instead agreed to a direct alliance with the industrialists.

At the end of 1963, Mesa Pajón received a letter from Enrique Peñalosa, the manager of INCORA, in which he declared that Pajón's extensive cattle ranch was in a state of underproduction and therefore was susceptible to being acquired and parcelled in the agrarian reform process. The landowner quotes the letter:

You can choose between selling to INCORA or growing sugarcane to request a subsequent right of exclusion, taking into account the provisions of Art. 72 in Law 135 of $1961 .^{12}$

This and other letters alerted the directors of SAG (the new union resulting from the merger of the Farmers Society of the Valley and the Departmental Committee of Livestock), whose president therefore decided to travel from Cali to Cartago to preside over an extraordinary meeting with 52 landowners and to establish a direct dialogue with the mills, Asocaña, and other stakeholders interested in the situation created by pressure from INCORA. In the course of this session and other additional meetings, agreements were reached between industrialists and landowners on sugarcane cultivation and the joint defence of land property. Thus, in a hearing held a few days later, SAG and Asocaña presented a unified position to the Minister of Agriculture and the INCORA directors. ${ }^{13}$

In Cartago in 1964, the strategies and agreements reached between industrialists and landowners inaugurated an alliance, mainly evidenced by a decision-making letter given to the SAG by the CVC Board of Directors, an entity originating in agro-industrial interests. ${ }^{14}$ This action, far from being a mere institutional operation, represents a ratification of the new institutional order of political power, being an alliance between powerful private proprietary economic sectors. This participation of landowners and industrialists in the CVC continues to influence government decision-making on issues such as rural investment, hydroelectric development, land drying, protection of private property, and adequate irrigation systems and water concessions.

This new alliance, through which the industrialists managed to convince the landowners to surrender to sugarcane cultivation, involved two major concessions by the mills. The first concession was disproportionate representation of the sugarcane purchase price in the cost. In 1978, whereas a medium-sized mill spent $\$ 69.6$ pesos to produce 1 ton of sugarcane on its property, sugar mills paid \$211.3 to the suppliers for the same ton (Fedesarrollo, 1976). This difference meant that during that year, payments to suppliers represented $203 \%$ more than the production costs.

The second concession involved supporting the landowners in their campaign opposing agrarian land reform. To a certain extent, this support implied a betrayal on the part of the mills of liberal reformist policies and their models

\footnotetext{
${ }^{11}$ AHSAG, Dispatched Correspondence: Jul-Sep 1970, Volume 17, fol. 1069e, Letter sent to regional authorities. AHSAG, Dispatched Correspondence: Apr-Jul 1970, Volume 16, fol. 1/31-3/0948, Letter sent to the Sociedad de Agricultores de Colombia [National Farmers Association-SAC].

${ }^{12}$ AHSAG, Dispatched Correspondence: Jan-Jun 1964, Volume 2, fol. 055, Letter by Salustio Victoria, SAG's Director, to Luis Bernardo Salcedo Cifuentes, President of the Finance Corporation of the Valle.

${ }^{13}$ AHSAG, Dispatched Correspondence: Jan-Jun 1964, Volume 2, fol. 0113, Letter by Salustio Victoria, SAG's Director, signed by landowners from the North of the Valle; fol. 0118, Letter by Rafael Carreño, SAG's Secretary, to SAC; fol. 0162. Letter by Salustio Victoria, SAG's Director, to Virgilio Barco, Ministry of Agriculture, and to Enrique Peñalosa Camargo, INCORA's President.

${ }^{14}$ AHSAG, Dispatched Correspondence: Jan-Jun 1964, Volume 2, fol. 0254. Letter to the Province Coffee Committee coordinating the designation to a representative in CVC.
} 
of agro-export development. Certainly, the excess costs paid to suppliers meant that during the 1960s, 1970s, and 1980s, Colombian production was not competitive in the international market. Thus, in 1970, when INCORA announced its policy of land expropriation and the creation of land consolidation in the plains of Jamundí (a municipality located in the southern Cauca River Valley), SAG, Asocaña, the chambers of commerce of the Cauca Valley, the industrial associations, FENALCO (National Trade Federation of Colombia), and the employers' workers unions joined to form "a front of all social classes against unsound INCORA procedures." ${ }^{15}$

Faced with the threat of expropriation, the landowners represented in SAG took an aggressive stance in the subsequent period, accusing INCORA officials of "inciting subversion" among the landless peasants. ${ }^{16}$ As a strategy to defend the property of the Jamundí landowners, the common front diversified their actions (a) by protesting through multiple letters to the central government; (b) by maintaining constant communication with the regional and national press criticizing INCORA actions; and finally, (c) by taking legal action against INCORA, led by SAG and supported by the sugarcane industrialist Henry Eder, director of the CVC.

The most impactful consequence of the aforementioned alliance was, without a doubt, the change in the regional productive system that, although it did not alter the land ownership structure, did exclude poor rural inhabitants from their historical access to common goods. An Afro-Colombian peasant from Alto Cauca accurately narrates this situation:

Let's talk about the Sardi as an example: they had farms and they had cattle. This is what their father, Don Aurelio Sardi, left them when he passed away. He [the father] had cattle, he planted rice, planted beans and other things. And, at first, the children followed suit, but over time, things were getting difficult, until finally the children were not able to continue growing crops, and they started planting sugarcane on their inherited property. Seeing that the sugarcane gave them positive results and they did not have so many people to worry about, they covered everything with sugarcane. Because they had so much land, they had to maintain a lot of workers: they had at least 10 or 15 workers in each cultivated area in the hacienda. In other words, it was easier to put in sugarcane than to provide money to the workers. With the new model of sugarcane plantations they did not have the need to worry, neither about the land nor about the people. (...) Now, they don't have any problems or concerns because now it is the mill that is concerned with the sugarcane: the mill does everything. ${ }^{17}$

The modalities of renting and provision enabled keeping the property structures intact without affecting the interests of the settled families. Consequently, during this period, the rural population was the most affected by transforming the hacienda model into a sugarcane-based agro-industrial model, because the institutional arrangements only included the politically and economically powerful sectors of the region, namely, the industrialists and landowners.

The phenomenon of outsourcing sugarcane production had a subsequent territorial effect. Although the peasant communities had previously been able to mediate control of the territory with some landowning families, they later had to contend with tenants who rotated frequently and failed to become permanent territorial actors. Between 1950 and 1968, sugarcane mills expelled peasants from an estimated 11,000 ha, and they then had to become smallholders, agricultural day labourers, or urban migrants (Giraldo, 2014). The testimony of an inhabitant of the Alto Cauca region reinforces this assertion:

Already at this time [1970], the farms were sold to the "rich", and there is a migration to Cali. The land was sold at the rate of one cow per hectare, and then the people gave up the land, and little by little,

\footnotetext{
${ }^{15}$ AHSAG, Dispatched Correspondence: Jul-Sep 1970, Volume 17, fol. 1, 31-40/1094 and forthcoming, Declaration of the SAG's Executive Board on the support by nonagricultural guild to the SAG.

${ }^{16}$ AHSAG, Dispatched Correspondence: Jul-Sep 1970, Volume 17, fol. 1069c. Complaint against a public officer from INCORA

${ }^{17}$ Interview with an 80-year-old Afro-descendant man from El Hormiguero, Valle del Cauca. November 2015.
} 
they sold the cows. In other words, it can be said that people ate their land! The families that migrated today intend to return to El Tiple ... but there is no land, and what land there is, they cannot afford. ${ }^{18}$

The Chicoral Pact, signed in 1971 under the auspices of conservative president Misael Pastrana, was a crucial mechanism that implicated the national government, landowners, and industrialists in reversing any land redistribution attempt as part of the agrarian reform. From this date forward, landowners have managed to permanently stop the sale of land, and industrialists have exerted greater control over INCORA's investment programmes, orientating these projects towards agrarian industrialization requirements: irrigation systems and dam and canal infrastructure.

(...) in 1963 it was estimated that there were 85,200 hectares under artificial irrigation and 61,642 under private irrigation. By 1975, it was estimated that INCORA had established projects on 208,200 hectares for a total of 355,000 irrigated hectares. (Bejarano, 1985, p. 264)

The entire line of credit developed through public banking has since facilitated the financing of agro-industry. Meanwhile, the peasantry of the region-as a social group-was excluded from the reconfiguration of formal contracts and informal agreements between landowners and industrialists over land use. The economic and political alliance among capitalist actors that supported agro-industrial land use resulted in communities losing autonomy and control over their territory and, consequently, in a forceful impact on their traditional culture, their social networks, and the type of environmental conservation favoured by their productive model.

\section{4 | Period III-Technological innovation and the consolidation of agro-industrial control (1975-1998)}

The alliance created between landowners and sugar industrialists gave way to a stage consolidating a sui generis agro-industrial model in which the industrializing impetus of some actors was moderated by sectors interested in preserving the structure of rural property. Since the mid-1970s, sugar mills have increasingly delegated sugarcane production activities (cultivation, irrigation, and harvesting) to private suppliers, allowing them to devote greater efforts to factory processes to obtain not only sugar but also honey, alcohol, and, later, ethanol.

The data from the 1990 bar in Figure 2 show how ownership over land ceased to be a decisive variable for defining the use applied to that land and reflects the indisputable importance of suppliers.

By using the questions posed by Bernstein (2010) to characterize rural agrarian politics, Table 1 allows us to analyse different land-tenure regimes in the latest period of sugarcane agrarian formation.

The capacity of suppliers to negotiate with industrialists has varied throughout time. Suppliers' bargaining power derives from the technical, financial, and administrative ability to cultivate sugarcane. A key element of this power is reflected in their negotiating capacity when determining the payment system by the mill (Rojas, 1983). However, usually, the mill imposes the rules and determines the price of sugarcane by the amount of sucrose extracted, rather than the weight of the sugarcane itself. This has forced growers to implement practices to improve the yield of sucrose per hectare-instead of increasing the productivity of sugarcane per hectare-for example, by engaging in the chemical ripening of the crop.

The intensive and extensive use of agrochemicals in large-scale plantations, including the use of glyphosate for chemical maturation, has significantly affected landowners due to a corresponding reduction in the availability and quality of water and soil (Pérez, Peña, \& Álvarez, 2011). Additionally, the glyphosate use by the sugarcane mills has been condemned by poor local inhabitants who have denounced the diverse damaging effects on their health and the environment derived from the use of this broad spectrum agrochemical, which in 2015 , was categorized by the WHO-IARC (2017) as "probably carcinogenic to humans."

${ }^{18}$ Workshop on historical memory with the community council by Afro-descendants from El Tiple. April 2016. 


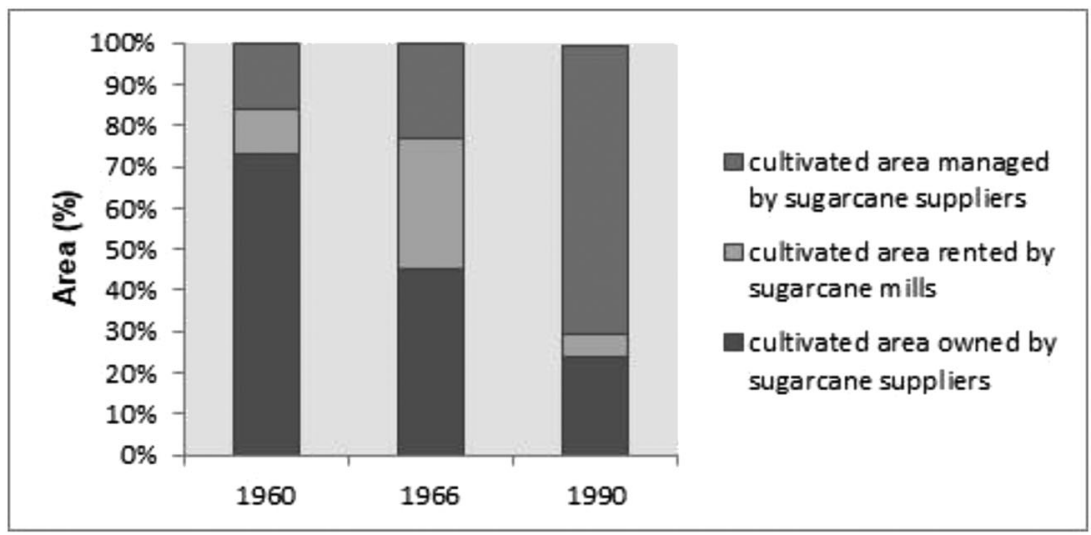

FIGURE 2 Evolution of the use and ownership of land cultivated with sugarcane in the geographical valley of the Cauca River between 1960 and 1990.

Source: Own design based on Ministerio de Agricultura y Desarrollo Rural (2006), Cenicaña (2000), and Rojas (1983, p. 149, 1985)

Although losing the environmental conditions for cultivation could generate a drop in land property prices, degradation results are irrelevant to the sugarcane mills, which can simply rotate between suppliers. It is the suppliers and landowners who accumulate environmental deprivation and are meant to take responsibility for generating technical conditions that allow the sugarcane to continue to grow. However, the consequences of environmental damage are arguably even more devastating to the peasant communities that historically inhabited these territories and who are now confronted with restricted access to those goods and services provided by the local ecosystems on which their livelihoods had been based (Vélez-Torres et al., 2013).

Through the suppliers, the mills have managed to ensure control over relevant technical conditions in the cultivation of sugarcane without having to formally own the land. Figure 3 shows the three main figures of land tenure: (a) sugarcane provided from land owned by the mills, (b) sugarcane provided from land leased by the mill, and (c) sugarcane provided by suppliers. The diagram also shows the figures for suppliers that have been explained in Table 1.

From the moment sugar mills changed their strategy of buying land to renting it and becoming buyers of sugarcane, it becomes more difficult to trace the magnitude of the dispossession that the industry has caused due to land grabbing; hence, it is more difficult to trace the responsibilities in the loss of "effective control" by poor rural inhabitants over the environmental resources of their territories (Borras \& Franco, 2010). In fact, since the mid-1990s, the emergence of a fourth social agent in the sugarcane landscape can be identified, one that can be described as a landless and outsourcing cultivator, dedicated to renting land while being responsible for cultivating sugarcane under the conditions defined by the mill up to the moment at which it delivers the raw material. The modalities of land use and ownership for sugarcane production, recorded in Figure 3, do not discriminate this emergent form of land use because the data analysed are those generated by the sugar industry, which is indifferent whether the supplier owns the land or not.

Poor peasant communities developed negotiation skills to influence the decisions made around the transformation of their territories and ecosystems. Faced with the restriction of legal opportunities to access both land ownership and land use, communities chose to articulate strategies and processes of social organization to occupy land. In particular, the first land seizure achieved by the Regional Indigenous Council of Cauca (CRIC) in the Hacienda López Adentro, located in the municipality of Candelaria, was carried out together with Afro-descendants who worked as day labourers in this same hacienda until 1982: 
TABLE 1 Mills' modes of access to sugarcane in the geographic valley of the Cauca River

\begin{tabular}{|c|c|c|}
\hline $\begin{array}{l}\text { Regimes of access to } \\
\text { sugarcane }\end{array}$ & Who owns what? & Who does what? \\
\hline \multicolumn{3}{|c|}{ Mill obtains sugarcane through self-supply } \\
\hline Mill owns the land & $\begin{array}{l}\text { The mill owns the land and } \\
\text { the sugarcane crop. }\end{array}$ & $\begin{array}{l}\text { Sugarcane cultivation and } \\
\text { sugar processing are } \\
\text { handled directly by the } \\
\text { sugar mill. }\end{array}$ \\
\hline Mill rents the land & $\begin{array}{l}\text { An individual person } \\
\text { exercises property rights } \\
\text { on the land and on the } \\
\text { sugarcane crop. }\end{array}$ & $\begin{array}{l}\text { Sugarcane cultivation and } \\
\text { sugar processing are } \\
\text { handled directly by the } \\
\text { sugar mill. }\end{array}$ \\
\hline
\end{tabular}

Who gains what?

The mill profits from the sale of sugar and derivatives from cane.

The landowner receives a related payment per hectare planted with cane. The sugar mill profits from the sale of sugar and other derivatives from cane.

Mill obtains sugarcane through external supply

Joint accounts

Supplier
An individual person owns the land and the sugarcane crop. However, a trade agreement is established with a sugar mill through which the landowner gives the crop to the mill to be fully maintained and harvested.
An individual person exercises property rights over the land. The landowner or a third person who pays rent to the landowner exercises property rights over the crop.

\section{Sugarcane cultivation and sugar processing are handled directly by the sugar mill.}

The landowner or leasing supplier sells the cane in the bush to the mill. The mill is responsible for the cutting, lifting, transport, and processing of sugar.
The landowner receives a payment related to the sugarcane sold according to a predefined contract. The sugar mill profits from the sale of sugar and other derivatives from sugarcane.

The landowner or leasing supplier receives a payment related to the sugarcane sold according to a predefined contract. The sugar mill profits from the sale of sugar and other derivatives from sugarcane.

aSource: Own design based on fieldwork observation and interviews, Cenicaña (2000), and Ministerio de Agricultura y Desarrollo Rural (2006).

We [the indigenous community] began to meet with them [Afro-descendant workers of the hacienda] at night. They knew the land well and also needed it because the rich did not leave anything to them. So we started organizing and making the land occupations like that: between Afros and us. The process of recovering land from our side was led by Julio Trochez, Rosalia Tilgo and Filomeno Musicue. ${ }^{19}$

As a result of this alliance between indigenous and Afro-descended people, both ethnic groups gained access to some land in the flat valley. The indigenous council of Corinto-López Adentro was founded at the same time that the black community councils were established around the areas of Monte Oscuro and Pílamo. However, when the recovery of land took place, the use of the land did not change for two reasons. First, the indigenous people from the mountain area did not know suitable cultivation techniques for the flat area, and second, the knowledge acquired

\footnotetext{
${ }^{19}$ Workshop on historical memory with the indigenous council from López Adentro. April 2016.
} 


\section{Total sugarcane provided to Sugarcane Mills}

\section{Sugarcane provided by Suppliers}

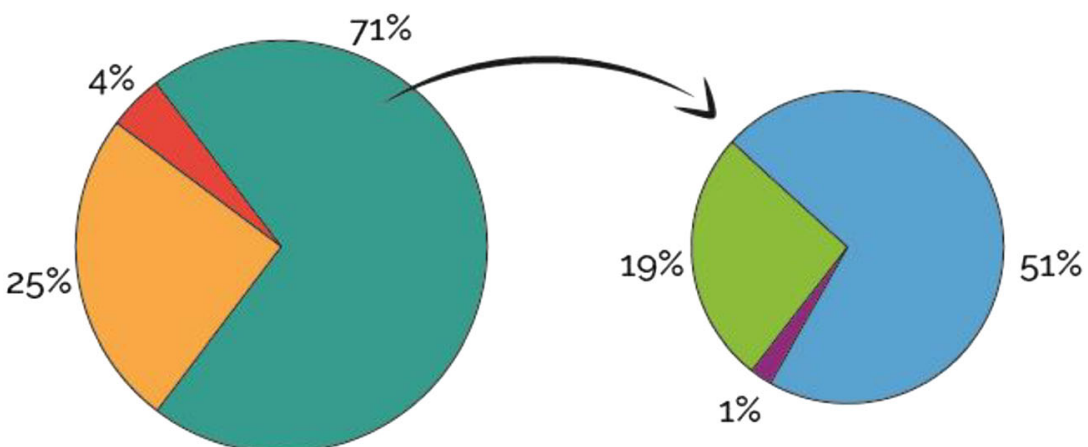

Provided from land owned by Sugarcane Mills

\section{Provided by Suppliers}

\section{Provided from land rented by} Sugarcane Mills
$51 \%$

\section{Joint accounts}

\section{Suppliers with administration}

\section{Suppliers}

FIGURE 3 Distribution of provided sugarcane to the mills in 1998. Source: Own design based on census of producers by Cenicaña (2000)

by Afro-descendants as day labourers of the haciendas only allowed them to give continuity to the standing agroindustrial production model.

[An indigenous woman said:] in the lowlands of López Adentro, sugarcane and rice were grown. And it was the Afros who taught us how to handle these crops and also how to apply the herbicides. They already brought this knowledge. ${ }^{20}$

The continuity of the monoculture model of production, even in the lands of indigenous and Afro-descendants, was welcomed by the mills, who simply incorporated these communities as "suppliers" of sugarcane.

The supplier-buyer relationship explains why it is the former landowners who used to own the land-and not the mills-who opposed the process of land occupation by both indigenous and Afro-descendants: For the mills, it is irrelevant who owns the land, as long as it is cultivated with sugarcane and the designated chemical maturation technology is applied. Poor peasant communities, despite owning land, generally do not achieve real territorial control because of difficulties in deciding what or how to cultivate, just as they do not gain food security when land use is monopolized by the monoculture.

Regional rural politics took a new turn after 1990. Drug-trafficking impacted property models in major cities and rural areas of the flat valley of the Cauca River. Since the end of 1990 and during the first half of 2000, organized paramilitary groups entered the region and engaged in land and land-based resource control; this role resulted in dirty relationships between landowners, industrialists, and paramilitary groups, eloquently described by the National 
Center of Historical Memory (Machado \& Rincon, 2014), a governmental organization created to disclose the social arrangements that have been at the basis of the internal armed conflict in Colombia. ${ }^{21}$

Although the archive studied in this research does not provide evidence of a previous liaison between industrialists, landowners, and armed groups, the complex and sophisticated socio-political relationships between the capitalist elite and the state have allowed the exercise of power through diversified forms of indirect violence. For example, indigenous and Afro-descendant people who have organized strategies to counter land grabbing through different forms of land recovery have experienced brutal repression by all kinds of armed actors, including paramilitary groups, guerrilla fighters, and the armed forces of the state.

With the arrival of ethanol in the mid-2000s, a new change has arisen in agrarian politics and the configuration of the sugarcane cluster. Despite the economic expectations driven by national laws created to support the obligatory use of biofuels since 2002, free trade has also generated negative impact: When the import of ethanol for domestic consumption was allowed in 2016, independently of the domestic supply, a great crisis was induced in the sugarcane cluster (see Resolution No. 41053/2016 of the Ministry of Mines and Energy). As a result, in 2017, the production of ethanol was reduced by 285\% compared with 2016 (Asocaña, 2018). New changes in the sugarcane cluster aim towards diversifying investment and colonizing new areas for pineapple, palm oil, and shrimp farming.

\section{5 | CONCLUSIONS: LOOKING BACK TO MOVE THE ANALYSIS FORWARD}

The analysis carried out here allows for the characterization of three periods from the emergence to the consolidation of the sugarcane landscape. Despite property having been mostly private, the interdependence and arrangements between social actors created a land-tenure regime where common access to natural resources was possible prior to the expansion of the sugarcane monoculture in the mid-20th century. The shifting constellation of agents, alliances, exclusions, and power exercises demonstrates the non-linear development of the Colombian agrarian sugarcane complex, reflecting the growing capacity of industrialists to monopolize the use of land, concentrate decisions on what agricultural techniques should be used, and thereby exercise hegemonic control over the territories.

Although family relations exist between landowners and industrialists, just as there have been other types of relationships such as the economic transformation from hacienda to mill, this article has analysed the differentiated role in the political economy of sugarcane, where sugar mills and landowners have demonstrated distinct social and economic behaviours. A complementary analysis is recommended through further research to understand family genealogies and establish connections between these two elitist agents and their possible repercussions on economic relations.

In particular, the analysed alliance between industrialists and landowners that emerged in 1964 made it possible to consolidate the industrialization promoted decades before by the central government without transforming the regional structures of land ownership. Our analysis allows us to reaffirm that after Law 135 of 1961, there has been no redistribution of property in the departments of Cauca and Valle del Cauca, but rather, a configuration of an agrarian model with two key capitalist agents-landowners and industrialists-and an excluded social group-the poor rural inhabitants-who did not benefit from increasing efficiency in the production of sugar and other derivatives such as ethanol.

The growth of the sugarcane monoculture at the cost of forests is confirmed by the loss of more than 16,000 ha of forest between 1957 and 1986 (Perafán, 2014). Further, comparing the agrarian census of 1959 (Universidad del Valle, 1963) with that of 1971 (Departamento Administrativo Nacional de Estadística, 1971), we observe that the expansion of sugarcane replaced not only transitory crops, including (soy)beans, cotton, and millet, but also displaced "other uses" fundamentally connected to the forests.

\footnotetext{
${ }^{21}$ For more on the relation between Cauca Valley industrialists and paramilitary groups, see also Barón (2016).
} 
The nature and role of governmental institutions, mechanisms, and arrangements, referred to by McKay (2018) as the state-society-capital nexus, have been crucial to the described agrarian change. In fact, the development of the sugarcane industry and the transformation of the old hacienda landscape was the result of the government's application of liberal doctrines, expressed in different reports contracted by the Colombian government to U.S. agencies and individuals: the Chardon Report in 1929 that recommended the scientific technification of agriculture; the Currie Mission of the World Bank in 1950 that proposed progressive taxation and punishment of the unproductive latifundia; and the Lillienthal plan, which in 1954, sought regional industrialization based on the adaptation of land, electrification, and transport infrastructure.

At the local level, the most important change in the relations with state institutions became evident after 1964 with two crucial facts. First, although strongly criticized at the time of its creation, the acceptance of the CVC by landowners led to the exploitation and protection of the institution by those same landowners in its function of promoting the quantitative adequacy of land. Second, and despite initially understanding the agrarian land reform as an opportunity to pressure landowners to convert their cattle lands into sugarcane plantations, the stance that the industrialists took against INCORA after 1964 changed their discourse from one of defending property against expropriation. By that time, the industrialists had realized that the only way they could guarantee their use of land would be by working with landowners in the defence of their property by slowly concentrating its use in the cultivation of sugarcane.

The greatest success of the landowners was to demonstrate that their land could be productive without needing to appeal the expropriation or purchase of land. A dramatic result of the alliance between the capitalist sectors that owned the land and industry was the crisis over the binary relationship that existed until the middle of the 20th century between poor landless peasants and landowners.

It can be observed that in any of the land-tenure regimes developed in the cultivation of sugarcane, the sugar mills did not relinquish control over how the sugarcane was grown. Either the mill itself continued to do all the cultivation work or it conditioned the purchase of the sugarcane as raw material having been cultivated under specific technical conditions, for example, the chemical maturation of the crop before harvesting. This control has generated confrontations between landowners and the sugar mills but has created greater conflict between the poor inhabitants and the sugar mills that they neighbour.

Land use and property have not been clearly distinguished in the academic account of Colombian agrarian history. This historical account has demonstrated that land property is just one of many factors playing a role in the tensions, arrangements, and conflicts among the social agents interspersed across the sugarcane landscape. The analysis presented here focused on the use and control over the land and land-based natural commons and allows different actors as well as their responsibilities to be distinguished with regard to specific forms of dispossession-forms that are blurred by an agrarian debate centred on land property.

As other researchers have argued for different geographies, constellations, and trajectories of land grabbing (Borras \& Franco, 2012; Hiraldo, 2018), capital enclosures have used sophisticated mechanisms-beyond land property-to colonize new spheres of nature and social relations. In fact, although the sugarcane landscape has not resulted in a radical change in land property regimes, it has resulted in a violent process of land-use transformation that has deeply affected the landless peasants, mainly Afro-descendants, through cumulative damage to their cultural heritage, social organization, traditional economies, and possible futures.

\section{ACKNOWLEDGEMENTS}

Many people have made this article possible. We are grateful to the Consejo Comunitario Hormiguero Palenque, the Cabildo Indígena Corinto-López Adentro, and the Historical Archive by the Sociedad de Agricultores y Ganaderos del Valle del Cauca-SAG. Three anonymous reviewers are thanked for critically reading a previous version of this paper and contributing with relevant suggestions that helped improve and clarify the manuscript. We thank the institutional support by the Universidad del Valle, Universidad Nacional de Colombia, and ICANH. 


\section{ORCID}

Irene Vélez-Torres (i) https://orcid.org/0000-0001-8566-6722

Diana Hurtado (D) https://orcid.org/0000-0001-5452-6970

\section{REFERENCES}

Almario, O. (1994). La configuración moderna del Valle del Cauca, Colombia, 1850-1940. cali: CECAN editores.

Asocaña (2018). Aspectos generales del sector agroindustrial de la caña 2017-2018. Informe Anual. Available from: https:// www.asocana.org/documentos/862018-E148DE81-00FF00,000A000,878787,C3C3C3,0F0F0F,B4B4B4, FF00FF,2D2D2D,A3C4B5.pdf (April 2019)

Barón, L. F. (2016). «Se nos salió de las manos ... ». Memorias de empresarios sobre el conflicto armado en el Valle del Cauca. Tabula Rasa, 24(1), 263-301.

Bejarano, J. A. (1985). Economía y poder. In La SAC y el desarrollo agropecuario colombiano, 1871-1984 (p. 264). Fondo editorial CEREC: Bogotá.

Bernstein, H. (2010). Class dynamics of agrarian change (Vol. 1). Canada: Fernwood Publishing and Kumarian Press.

Borras Jr., S. \& Franco, J. (2010). Towards a broader view of the politics of global land grab: Rethinking land issues, reframing resistance. Working Paper Series No. 001. Initiatives in Critical Agrarian Studies (ICAS). The Hague: International Institute of Social Studies (ISS). Available from: http://www.iss.nl/icas/ (April 2019).

Borras, S. Jr., \& Franco, J. (2012). Global land grabbing and trajectories of agrarian change: A preliminary analysis. Journal of Agrarian Change, 12(1), 34-59. https://doi.org/10.1111/j.1471-0366.2011.00339.x

Borras, S. Jr., Hall, R., Scoones, I., White, B., \& Wolford, W. (2011). Towards a better understanding of global land grabbing: An editorial introduction. The Journal of Peasant Studies, 38(2), 209-216.

Brunckhorst, D. (2010). Using context in novel community-based natural resource management: Landscapes of property, policy and place. Environmental Conservation, 37(1), 16-22. https://doi.org/10.1017/S0376892910000342

Bürgi, M., Hersperger, A., \& Schneeberger, N. (2005). Driving forces of landscape change-current and new directions. Landscape Ecology, 19(8), 857-868. https://doi.org/10.1007/s10980-005-0245-3

CENICAÑA. (2000). Los clientes de la nueva tecnología. Censo y tipificación de productores de caña de azúcar de la industria azucareracolombiana, 1998. Serie técnica No. 27. Cali, Colombia.

Collins, C. (1983). Formación de un sector de clase social: La burguesía azucarera en el Valle del Cauca durante los años treinta y cuarenta. Revista Historia y Espacio, 3(9), 43-112.

Colmenares, G. (1976). Cali: terratenientes, mineros y comerciantes, siglo XVIII. Cali: Universidad del Valle.

Dávila, L., \& de Guevara, C. (2013). In Universidad de los Andes (Ed.), Empresariado en Colombia: perspectiva histórica y regional. Bogotá.

Universidad del Valle (1963). Censo agropecuario del Valle del Cauca - 1959. Cali: Universidad del Valle, Facultad de Ciencias Económicas.

Departamento Administrativo Nacional de Estadística (DANE) (1971). Censo Nacional Agropecuario (pp. 1970-1971). Valle, Cauca y Nariño. Bogotá: Departamento Administrativo Nacional de Estadística (DANE).

Díaz, Z. (1983). In Biblioteca Banco Popular \& Universidad del Valle (Ed.), Guerra y economía en las haciendas. Popayán (pp. 1780-1830). Bogotá.

Dye, A., \& Sicotte, R. (2004). The US sugar program and the Cuban revolution. The Journal of Economic History, 64(3), 673-704. https://doi.org/10.1017/S0022050704002931

Fadul, M., \& Peñalosa, E. (1961). La industria azucarera en la economía colombiana. Cali: Carvajal.

Fedesarrollo (1976). Las industrias azucarera y panelera en Colombia. Fedesarrollo: Bogotá.

Giraldo, R. (2014). Reconfiguración del paisajey agroecología en el Valle del Cauca, 1850-2010. Revista Luna Azúl, 38, 252-273.

Gosden, C., \& Head, L. (1994). Landscape-A usefully ambiguous concept. Archaeology in Oceania, 29(3), 113-116. https:// doi.org/10.1002/arco.1994.29.3.113

Hall, R. (2011). Land grabbing in Southern Africa: The many faces of the investor rush. Review of African Political Economy, 38(128), 193-214. https://doi.org/10.1080/03056244.2011.582753

Hersperger, A., \& Bürgi, M. (2009). Going beyond landscape change description: Quantifying the importance of driving forces of landscape change in a Central Europe case study. Land Use Policy, 26(3), 640-648. https://doi.org/10.1016/j. landusepol.2008.08.015

Higman, B. W. (2000). The sugar revolution. Economic History Review LIII(2), 53, 213-236. https://doi.org/10.1111/14680289.00158 
Hiraldo, R. (2018). Experiencing primitive accumulation as alienation: Mangrove forest privatization, enclosures and the everyday adaptation of bodies to capital in rural Senegal. Journal of Agrarian Change, 18(3), 517-535. https://doi.org/10. 1111/joac.12247

Hurtado, D. (2017). El monocultivo de la caña de azúcar, un vecino hostil. Acumulación por control en el contexto de las fumigaciones y el monocultivo de la caña de azúcar en El Hormiguero (Cali). Monograph MsC in Sustainable Development, Universidad del Valle (pp. 123).

Machado, A., \& Rincon, J. J. (2014). "Patrones" y campesinos: tierra, poder y violencia en el Valle del Cauca (1960-2012). Bogotá: Centro Nacional de Memoria Histórica. Available from: http://www.centrodememoriahistorica.gov.co/ descargas/informes2014/patronesyCampesinos/patrones-y-campesinos-tierra-poder-violencia-valle-del-caucainsertos-baja.pdf (April 2019)

Marull, J., Pino, J., Tello, E., \& Cordobilla, M. (2010). Social metabolism, landscape change and land-use planning in the Barcelona Metropolitan Region. Land Use Policy, 27(2), 497-510. https://doi.org/10.1016/j.landusepol.2009.07.004

McCay, B. J., \& Acheson, M. (Eds.) (1990). The question of the commons: The culture and ecology of communal resources. USA: University of Arizona Press.

McKay, B. (2018). The politics of agrarian change in Bolivia's soy complex. Journal of Agrarian Change, 18(2), 406-424. https://doi.org/10.1111/joac.12240

Ministerio de Agricultura y Desarrollo Rural. (2006). Observatorio Agrocadenas: Agroindustria y Competitividad, Anuario 2005. https://orton.catie.ac.cr/repdoc/A9168e/A9168e.pdf

Muñoz Guerrero, D., \& Gómez-Zotano, J. (2016). Propuesta metodológica para la gestión de los paisajes de páramo en el marco de la Iniciativa Latinoamericana del Paisaje (LALI). Perspectiva Geográfica, 21(2), 225-250.

National Productivity Center [Centro Nacional de Productividad - CNP] (2002). El conglomerado del Azúcar del Valle del Cauca, Colombia. Revista CEPAL-SERIE Desarrollo productivo No. 134 (pp. 44). https://www.cepal.org/es/publicaciones/ 4523-conglomerado-azucar-valle-cauca-colombia

Ostrom, E., et al. (Eds.) (2002). The drama of the commons. USA: National Academy Press.

Perafán, A. (2014). Transformaciones paisajisticas en la zona plana vallecaucana. Historia y Espacio, 1(24), 111-139. https:// doi.org/10.25100/hye.v1i24.1231

Pérez, M., Peña, M., \& Álvarez, P. (2011). Agro-industria cañera y uso del agua: análisis crítico en el contexto de la política de agrocombustibles en Colombia. Ambiente y Sociedade, 14(2), 153-178. https://doi.org/10.1590/S1414$753 \times 2011000200011$

Presidencia de la República, Dirección Nacional de Planeación Económica y Fiscal (1954). Plan Valle del Cauca, inversiones 1954-1958 [Known as Plan Lilienthal]. Bogotá: Imprenta del Banco de la República.

Raworth, K. (2017). Doughnut economics: Seven ways to think like a 21st-century economist. Chelsea Green Publishing.

Rojas, J. M. (1983). In Biblioteca Banco Popular \& Universidad del Valle (Ed.), Empresarios y tecnología en la formación del sector azucarero en Colombia (pp. 1860-1980). Bogotá.

Rojas, J. (1985). Conferencia ante estudiantes de Administración de Empresas, Universidad Externado de Colombia, Bogota. Noviembre 9 y 10. http://cms.univalle.edu.co/socioeconomia/media/ckfinder/files/Sobreelpapeldelosempresarios enlaformaciondelsectorazucarero.pdf

Sullivan, G., \& Osborne, B. (1998). The drama of landscape: Land, property, \& social relations on the early modern stage (p. 292). Stanford, California: Stanford University Press.

Taussig, M., \& Rubbo, A. (2011). Esclavitud y libertad en el valle del río Cauca. Bogotá: Universidad de Los Andes.

Tello, E., Jover, G., Murray, I., Fullana, O., \& Soto, R. (2018). From feudal colonization to agrarian capitalism in Mallorca: Peasant endurance under the rise and fall of large estates (1229-1900). Journal of Agrarian Change, 18(3), 483-516. https://doi.org/10.1111/joac.12253

Valencia-Llano, N. F. (2015). La agricultura científica en el departamento del Valle del Cauca, Colombia: génesis e irrupción (pp. 1910-1946). Palmira: Universidad Nacional de Colombia-sede Palmira.

Vélez-Torres, I., \& Varela, D. (2014). Between the paternalistic and the neoliberal state. Dispossession and resistance in Afro-descendant communities of the Upper Cauca, Colombia. Latin American Perspectives, 41(6), 9-26. https://doi.org/ 10.1177/0094582X14547515

Vélez-Torres, I., Varela, D., Rátiva, S. \& Salcedo, A. (2013). Agroindustria y extractivismo en el Alto Cauca. Impactos sobre los sistemas de subsistencia Afro-campesinos y resistencias (1950-2011). C.S. 12, 157-188.

Vila Subirós, J., Varga Linde, D., Llausas Pascual, A., \& Ribbas Palom, A. (2006). Conceptos y métodos fundamentales en ecología del paisaje (landscape ecology). Una interpretación desde la geografía. Documents d'anàlisi geogràfica, 48, 151-166.

Villamil Chaux, C. (2011). La Reforma Agraria del Frente Nacional: De la concentración parcelaria de Jamundí al pacto de Chicoral. Monografía para optar al título de Magíster en Historia, Universidad de los Andes.

Von Benda-Beckmann, F., von Benda-Beckmann, K., \& Wiber, M. (Eds.) (2006). Changing properties of property. Oxford: Berghahn Books. 
WHO-IARC (2017). Evaluation of five organophosphate insecticides and herbicides. IARC Monographs on the evaluation of carcinogenic risks to human, Volume 112.

Williamson, T., \& Bellamy, L. (1987). Property and landscape (p. 240). London: George Philip.

Yifeng, W. (2008). Theory of property rights: Comparing Marx with Coase. Social Sciences in China-English Edition, 29(2), 5-17.

REVISTA AGRÍCOLA Y GANADERA [AGRICULTURAL AND LIVESTOCK MAGAZINE]

Revista Agrícola y Ganadera No. 133, Feb 1951

Revista Agrícola y Ganadera No. 136, May 1951

Revista Agrícola y Ganadera No. 199, Dec 1956

Revista Agrícola y Ganadera No. 206, Jul 1957

Revista Agrícola y Ganadera No. 216, Oct-Nov 1958

Revista Agrícola y Ganadera No. 234, Nov 1960

Revista Agrícola y Ganadera No. 251, Jun 1963

Revista Agrícola y Ganadera No. 252, Oct-Nov 1963

\section{ARCHIVO HISTÓRICO DE LA SAG (AHSAG) [HISTORICAL ARCHIVE BY THE SAG]}

Dispatched Correspondence: Jul-Dec 1963, Volume 1, fol. 0024.

Dispatched Correspondence: Jan-Jun 1964, Volume 2, fol. 0113.

Dispatched Correspondence: Jan-Jun 1964, Volume 2, fol. 0118.

Dispatched Correspondence: Jan-Jun 1964, Volume 2, fol. 0162.

Dispatched Correspondence: Jul-Sep 1970, Volume 17, fol. 1, 31-40, 1094.

Dispatched Correspondence: Jul-Sep 1970, Volume 17, fol. 1069c.

\section{ORCID}

Irene Vélez-Torres (iD) https://orcid.org/0000-0001-8566-6722

Diana Hurtado (D) https://orcid.org/0000-0001-5452-6970

How to cite this article: Vélez-Torres I, Varela D, Cobo-Medina V, Hurtado D. Beyond property: Rural politics and land-use change in the Colombian sugarcane landscape. J Agrar Change. 2019;19:690-710. https://doi.org/10.1111/joac.12332 